\title{
Fauna of Noctuidae (Lepidoptera: Noctuoidea) in a pasture area in Altamira, Eastern Amazon, Pará, Brazil
}

\author{
Almeida, LP. ${ }^{a}$, Specht, $A^{b}$ and Teston, JA. ${ }^{c *}$ \\ ${ }^{a}$ Faculdade de Ciências Biológicas, Universidade Federal do Pará - UFPA, Rua José Porfírio, 2515, \\ CEP 68372-070, Altamira, PA, Brazil \\ 'Laboratório de Entomologia, EMBRAPA Cerrados, BR 020 Km 18, CEP 73310-970, Planaltina, DF, Brazil \\ 'Programa de Pós-graduação em Recursos Naturais da Amazônia - PPGRNA, Programa de Ciências Naturais e \\ Laboratório de Estudos de Lepidópteros Neotropicais, Universidade Federal do Oeste do Pará - UFOPA, \\ Rua Vera Paz, s/n, CEP 68040-255, Santarém, PA, Brazil \\ *e-mail: jateston@ufpa.br; jateston@gmail.com
}

Received: May 10, 2013 - Accepted: June 10, 2013

(With 3 figures)

\begin{abstract}
This study evaluated the nocturnal fauna of Noctuidae in a pasture area in Altamira, Pará. Samples were collected monthly for two nights at the new moon period, from August 2007 to July 2008. We collected a total of 345 specimens (N) of 66 species (S). The most abundant species were Ptichodes basilans (Guenée) (n=87), Leucania jaliscana (Schaus), Spodoptera frugiperda (JE Smith) $(\mathrm{n}=28)$ and Argidia palmipes Guenée $(\mathrm{n}=21)$. For the entire period, the following indexes were found: Shannon diversity $H^{\prime}=3.20$ and Brillouin $H=2.94$, evenness of Shannon $E^{\prime}=0.76$ and Brillouin $\mathrm{E}=0.76$, and Berger-Parker dominance $\mathrm{BP}=0.252$. The greatest diversity was found in the dry season. According to the estimates of species richness, it is possible that between 14 to 72 more species exist in the region.
\end{abstract}

Keywords: biodiversity, community structure, Neotropical region, owlet-moths.

\section{Fauna de Noctuidae (Lepidoptera: Noctuoidea) em uma área de pastagem na Amazônia Oriental em Altamira, Pará, Brasil}

\section{Resumo}

A diversidade de Noctuidae noturnos foi estudada em área de pastagem em Altamira, Pará. As coletas foram feitas com armadilha luminosa, mensalmente durante duas noites no período de lua nova, entre agosto de 2007 a julho de 2008. Foi coletado um total de 345 espécimes (N) de 66 espécies (S). As espécies mais abundantes foram Ptichodes basilans (Guenée) (n=87), Leucania jaliscana (Schaus), Spodoptera frugiperda (J.E. Smith) $(\mathrm{n}=28)$ e Argidia palmipes Guenée $(\mathrm{n}=21)$. Para todo o período de estudo foram encontrados os seguintes índices: diversidade de Shannon $\mathrm{H}^{\prime}=3,20$ e de Brillouin $\mathrm{H}=2,94$, uniformidade de Shannon $\mathrm{E}^{\prime}=0,76$ e Brillouin $\mathrm{E}=0,76$, e dominância Berger-Parker $\mathrm{BP}=0,252$. A estação menos chuvosa apresentou maior diversidade. As estimativas de riqueza apresentaram a possibilidade de se encontrar entre 14 a 72 espécies a mais.

Palavras-chave: biodiversidade, estrutura da comunidade, Região Neotropical, mariposas.

\section{Introduction}

The traditional occupation model of the Amazon has significantly increased local deforestation (Alves, 2001), which in turn has caused loss of soil fertility, changes in the hydrological regimen, emission of greenhouse gases, and loss of biodiversity (Fearnside, 2005).

In Altamira, the original forest cover has undergone a considerable change, especially in the area of influence of the Transamazônica highway (BR-230). On average, $60 \%$ of the original vegetation has been converted into various types of land uses, including short cycle sustainable agriculture, pastures for cattle, and perennial crops such as cocoa and black pepper (Salomão et al., 2007).
Though scarce, studies on the temporal diversity of the invertebrates that inhabit the Amazon is important, because they generate necessary information on the seasonal variations of various species. Knowing their time of occurrence allows for more accurate assessments of the conservation status of the wildlife in a certain place (Teston et al., 2012).

Moths are widely used in the study and conservation of biological diversity. Among them, Noctuidae is the most diverse family, making up for most Lepidoptera sampled with light traps (Gaston, 1988; Chey et al., 1997). Light trap data are used for sampling populations of pest 
species, and studying their dynamics, population ecology, migrations, behavioral aspects of flight and relationships with host plants (Chey et al., 1997). The present study evaluated the diversity and seasonality of the nocturnal fauna of Noctuidae during one year, from August 2007 to July 2008 .

\section{Material and Methods}

Specimens were collected monthly for two nights during the new moon, between August 2007 and July 2008, at the Ranch Vista Alegre, municipality of Altamira, Pará. The collection point is located at the following coordinates: $03^{\circ} 07^{\prime} 22^{\prime \prime} \mathrm{S}$ and $52^{\circ} 15^{\prime} 17^{\prime \prime} \mathrm{W}$, with an average of 130 $\mathrm{m}$ a.s.l., an area of grassland with use of nearly 25 years. The vegetation consists of grass and some scattered trees. Approximately 150 meters in front of it, there is a meadow which has been preserved for about fifteen years. Approximately $100 \mathrm{~m}$ on the right side of it, a water spring and a pond surrounded by riparian vegetation can be found.

The moths were captured with EMATER / RS light traps model "Santa Rosa", placed in such a manner that the lower portion of the trap stands two meters above the ground. Light traps were powered by $12 \mathrm{~V}$ batteries at dusk and were left off in the morning (Teston and Delfina, 2010).

In the region, the period when rain is most intense extends from December to May, and the drier period goes from June to November (Moraes et al., 2005). During the sampling period, the average temperature was $27.2^{\circ} \mathrm{C}$ and the rainfall was $2,399.7 \mathrm{~mm}$, according to the National Institute of Meteorology (INMET). The seasonality was obtained considering that the rainiest season, from December 2007 to May 2008, had a total rainfall of 2,001.1 mm, and the drier seasons, from August to November 2007 and June and July 2008, had total rainfall of $398.6 \mathrm{~mm}$.

The specimens were identified by the second author, a Noctuid expert, and classified into subfamilies according to the system devised by Poole (1989). In the analysis, we evaluated the constancy of each species each month, ranking them according to Bodenheimer, as referred to by Silveira Neto et al. (1976), in: (1) constant, (2) accessory (3) accidental. The species dominance was classified according to Ott and Carvalho (2001): (A) rare, (B) eventual, (C) subdominant; (D) dominant and (E) eudominant.

The following parameters were evaluated: richness $(\mathrm{S})$, abundance $(\mathrm{N})$, diversity indices of Shannon $\left(\mathrm{H}^{\prime}\right)$ and Brillouin (H), uniformity indices of Shannon's (E') and Brillouin (E), and dominance index of Berger-Parker (BP) (Magurran, 2004). The values of H', between seasonal periods, were compared by the " $\mathrm{t}$ " test proposed by Hutcheson (1970). The similarity between the months was assessed using the NMDS method, using the similarity coefficient of Bray-Curtis using the software PAST version 2.06 (Hammer et al., 2001).

To estimate Noctuidae richness, we used the program "EstimateS 8.2.0" (Colwell, 2009), and the nonparametric "Bootstrap", "Chao1", "Chao2", "Jackknife1", "Jackknife2" and "Michaelis-Mentem", with 1,000 randomizations (Colwell and Coddington, 1994). Also, the rarefaction of species curve was constructed using the index of "Mao Tau", with a confidence interval of $95 \%$.

\section{Results}

We collected 345 specimens $(\mathrm{N})$ in 66 species $(\mathrm{S})$, distributed in nine subfamilies: Amphypirinae, Catocalinae, Euteliinae, Hadeninae, Heliothinae, Herminiinae, Noctuinae, Ophiderinae and Plusiinae (Table 1).

Catocalinae, Ophiderinae and Hadeninae were the most abundant, and the highest richness was found in Ophiderinae, Amphypinae and Catocalinae. The most abundant species were Ptichodes basilans, with 87 specimens (25.2\%), Leucania jaliscana and Spodoptera frugiperda, each with 28 (8.1\%) specimens and Argidia palmipes, with 21 specimens captured $(6.1 \%)$ (Table 1).

With respect to constancy (Table 1), only L. jaliscana and $P$. basilans $(3.0 \%)$ were constant, 12 species were accessory (18.2\%) and 52 were acidental (78.8\%). The categories of dominance (Table 1) indicated that 45 species $(68.2 \%)$ are rare, nine (13.6\%) are eventual, seven (10.6\%) are subdominant, four (A. palmipes, Leucania humidicola, L. jaliscana and S. frugiperda) (6.1\%) are dominant, and only P. basilans $(1.5 \%)$ is eudominant.

Comparing the seasonal periods with less (drier) and more rain (Figure 1), the highest species richness, with $\mathrm{S}=49(74.2 \%)$, was found in the first. By contrast, abundance of specimens was greater with more rain: $\mathrm{N}=181(52.5 \%)$. The diversity and evenness indices were higher in the period with less rain, with $\mathrm{H}^{\prime}=3.33$ and $\mathrm{E}^{\prime}=0.85$ for Shannon, and $\mathrm{H}=2.95$ and $\mathrm{E}=0.86$ for Brillouin. The highest dominance was found in the period of more intense rain, with $\mathrm{BP}=0.381$. Thus the least rainy season showed the highest diversity index and evenness (Table 2).

In the NMDS (Figure 2) it was possible to observe the separation between years, but there is no a distinction between the seasonal periods of more and less rain, however, the months of the rainy season in January and February 08 were very close, this also occurred between May 08 (end of the rainy season) and June 08 (early dry season).

Estimates of species richness (Table 3) showed different values, the "Bootstrap" revealed the possibility to find 81 species, $22.7 \%$ more that the actual number found. The "Michaelis-Mentem" indicates the existence of 170 $(157.6 \%)$ more species. The highest richness estimates were in the season with less rain; only the "Chao 1" was greater for the period of more rain. The species rarefaction curve (Figure 3) shows no a tendency to asymptote confirming what was presented by the richness estimators.

\section{Discussion}

The abundance and richness found in this study were lower than those obtained after intensive collecting, conducted in four protected areas of Rio Grande do Sul (Specht et al., 2005), including an area in a biome known as "Campos Sulinos", where we observed the lowest values of abundance (944) and richness (83). The number 
Table 1. Number of specimens, constancy $(1=$ constant; $2=$ accessory; $3=$ accidental $)$ and dominance $(A=$ rare; $B=$ eventual; $\mathrm{C}$ = subdominant; $\mathrm{D}=$ dominant; and $\mathrm{E}=$ eudominant) of Noctuidae in Altamira, eastern Amazon, state of Pará, Brazil.

\begin{tabular}{|c|c|c|c|}
\hline \multirow{2}{*}{ Subfamily / Species } & \multicolumn{3}{|c|}{ Period } \\
\hline & +Rain & - Rain & Total \\
\hline \multicolumn{4}{|l|}{ Amphypirinae } \\
\hline Callopistria floridensis (Guenée, 1852) ${ }^{\text {(3) (A) }}$ & 1 & 0 & 1 \\
\hline Condica cupentia (Cramer, 1780) ${ }^{(3)(\mathrm{A})}$ & 1 & 2 & 3 \\
\hline Condica sutor (Guenée, 1852) (3)(A) & 0 & 1 & 1 \\
\hline Condica vecors (Guenée, 1852) (3)(A) & 1 & 0 & 1 \\
\hline Elaphria agrotina (Guenée, 1852) ${ }^{(3)(\mathrm{A})}$ & 0 & 2 & 2 \\
\hline Elaphria deltoides (Möschler, 1880) (3)(A) & 1 & 0 & 1 \\
\hline Hampsonodes bilineata (Maassen, 1890) ${ }^{\text {(3) (A) }}$ & 0 & 2 & 2 \\
\hline Hampsonodes dislocata (Walker, [1857]) ${ }^{(3)(\mathrm{B})}$ & 0 & 4 & 4 \\
\hline Hampsonodes naevia (Guenée, 1852) ${ }^{(3)(\mathrm{A})}$ & 1 & 0 & 1 \\
\hline Magusa orbifera (Walker, 1857) ${ }^{(3)(\mathrm{A})}$ & 1 & 1 & 2 \\
\hline Spodoptera albula (Walker, 1857) ${ }^{(3)(\mathrm{A})}$ & 2 & 0 & 2 \\
\hline Spodoptera androgea (Stoll, 1782) (3)(A) & 1 & 0 & 1 \\
\hline Spodoptera frugiperda (J. E. Smith, 1797) (2)(D) & 5 & 23 & 28 \\
\hline Spodoptera marima (Schaus, 1904) ${ }^{(3)(\mathrm{C})}$ & 4 & 7 & 11 \\
\hline \multicolumn{4}{|l|}{ Catocalinae } \\
\hline Acanthodica sp. ${ }^{(3)(\mathrm{A})}$ & 0 & 1 & 1 \\
\hline Dysgonia purpurata Kaye, $1901^{(3)(\mathrm{A})}$ & 1 & 0 & 1 \\
\hline Mocis latipes (Guenée, 1852) (3)(B) & 4 & 0 & 4 \\
\hline Nymbis prolixa (C. Felder \& Rogenhofer, 1874) ${ }^{(2)(C)}$ & 11 & 2 & 13 \\
\hline Perasia helvina (Guenée, 1852) (3)(A) & 0 & 1 & 1 \\
\hline Perasia ora (Cramer, 1776) ${ }^{(3)(\mathrm{A})}$ & 0 & 1 & 1 \\
\hline Ptichodes agrapta (Hampson, 1913) ${ }^{(3)(\mathrm{C})}$ & 5 & 3 & 8 \\
\hline Ptichodes basilans (Guenée, 1852) ${ }^{(1)(\mathrm{E})}$ & 69 & 18 & 87 \\
\hline Ptichodes sp. ${ }^{(2)(\mathrm{C})}$ & 5 & 2 & 7 \\
\hline Zale viridans (Guenée, 1852) (3)(A) & 0 & 2 & 2 \\
\hline Catocalinae sp. ${ }^{(3)(A)}$ & 0 & 1 & 1 \\
\hline \multicolumn{4}{|l|}{ Euteliinae } \\
\hline Eutelia abscondens (Walker, 1858) (3) (A) & 0 & 1 & 1 \\
\hline \multicolumn{4}{|l|}{ Hadeninae } \\
\hline Leucania jaliscana Schaus, $1898^{(1)(\mathrm{D})}$ & 19 & 9 & 28 \\
\hline Leucania humidicola Guenée, $1852^{\text {(2) (D) }}$ & 11 & 8 & 19 \\
\hline Pseudaletia adultera (Schaus, 1894) ${ }^{(3)(\mathrm{A})}$ & 0 & 2 & 2 \\
\hline Pseudaletia sequax Franclemont, 1951 (2)(C) & 4 & 5 & 9 \\
\hline Xanthopastis timais (Cramer, 1780) ${ }^{(3)(\mathrm{A})}$ & 1 & 0 & 1 \\
\hline \multicolumn{4}{|l|}{ Heliothinae } \\
\hline Shinia sp. ${ }^{(3)(\mathrm{B})}$ & 1 & 3 & 4 \\
\hline \multicolumn{4}{|l|}{ Herminiinae } \\
\hline Herminiinae sp. ${ }^{(3)}(\mathrm{A})$ & 0 & 2 & 2 \\
\hline \multicolumn{4}{|l|}{ Noctuinae } \\
\hline Agrotis repleta Walker, $1857^{\text {(3) (A) }}$ & 0 & 1 & 1 \\
\hline \multicolumn{4}{|l|}{ Ophiderinae } \\
\hline Alabama argillacea (Hübner, 1823) ${ }^{(3)(\mathrm{A})}$ & 1 & 0 & 1 \\
\hline Anoba flavilinea Hampson, $1926^{(2)(B)}$ & 0 & 4 & 4 \\
\hline Argidia palmipes Guenée, $1852^{(2)(\mathrm{D})}$ & 5 & 16 & 21 \\
\hline Coenipeta bibitrix (Hübner, 1823) (3)(A) & 0 & 1 & 1 \\
\hline Coenipeta polynoe (Gueneé, 1852) (3)(A) & 0 & 1 & 1 \\
\hline Coenipeta sp. ${ }^{(3)(\mathrm{A})}$ & 1 & 0 & 1 \\
\hline Coenipeta zenobina (Massen, 1890) (2) (B) & 2 & 2 & 4 \\
\hline
\end{tabular}


Table 1. Continued...

\begin{tabular}{|c|c|c|c|}
\hline \multirow{2}{*}{ Subfamily / Species } & \multicolumn{3}{|c|}{ Period } \\
\hline & +Rain & - Rain & Total \\
\hline Diphtera festiva (Fabricius, 1775) ${ }^{(3)(\mathrm{A})}$ & 0 & 2 & 2 \\
\hline Dyomyx fumata (C. Felder \& Rogenhofer, 1874) ${ }^{\text {(3) (A) }}$ & 0 & 1 & 1 \\
\hline Euclystis guerini (Guenée, 1852) (3)(A) & 1 & 0 & 1 \\
\hline Euclystis terraba (Schaus, 1911) ${ }^{(3)(\mathrm{A})}$ & 0 & 1 & 1 \\
\hline Eulepidotis candida (Bar, 1876) ${ }^{(3)(\mathrm{A})}$ & 0 & 1 & 1 \\
\hline Eulepidotis jucinda (Gueneé, 1852) (3)(A) & 0 & 2 & 2 \\
\hline Eulepidotis juliata (Stoll, 1790) ${ }^{(2)(\mathrm{C})}$ & 1 & 6 & 7 \\
\hline Eulepidotis rectimargo (Guenée, 1852) (3)(B) & 2 & 2 & 4 \\
\hline Eulepidotis sp. ${ }^{(3)(\mathrm{A})}$ & 1 & 0 & 1 \\
\hline Gonodonta bidens Geyer, $1832^{(2)(C)}$ & 1 & 8 & 9 \\
\hline Gonodonta sicheas (Cramer, 1777) ${ }^{(3)(\mathrm{A})}$ & 0 & 1 & 1 \\
\hline Hemeroblemma sp. ${ }^{(3)(A)}$ & 0 & 1 & 1 \\
\hline Letis occidua (Linnaeus, 1758) ${ }^{(3)(\mathrm{A})}$ & 0 & 1 & 1 \\
\hline Letis xylia Guenée, $1852^{(2)(\mathrm{B})}$ & 5 & 0 & 5 \\
\hline Melipotis perpendicularis (Guenée, 1852) ${ }^{(3)(\mathrm{A})}$ & 2 & 0 & 2 \\
\hline Peteroma jarinta Schaus, $1901^{\text {(3) (A) }}$ & 0 & 1 & 1 \\
\hline Peteroma lignea Schaus, $1906^{(3)(\mathrm{A})}$ & 0 & 1 & 1 \\
\hline Polygoniodes laciniata (C. Felder \& Rogenhofer, 1874) ${ }^{\text {(3) (A) }}$ & 1 & 0 & 1 \\
\hline Selenisa suero (Cramer, 1777) ${ }^{(3)(\mathrm{A})}$ & 1 & 1 & 2 \\
\hline Selenisa sueroides (Guenée, 1852) (2)(B) & 3 & 1 & 4 \\
\hline Smyra stipatura (Walker, 1858) (3)(A) & 1 & 1 & 2 \\
\hline Sosxetra grata Walker, $1862^{(2)(\mathrm{B})}$ & 2 & 2 & 4 \\
\hline Thysania zenobia (Cramer, 1777) ${ }^{(3)(\mathrm{A})}$ & 1 & 0 & 1 \\
\hline Ophiderinae sp. ${ }^{(3)(\mathrm{A})}$ & 0 & 2 & 2 \\
\hline \multicolumn{4}{|l|}{ Plusiinae } \\
\hline Pseudoplusia includens (Walker, [1858]) ${ }^{\text {(3) (A) }}$ & 1 & 1 & 2 \\
\hline
\end{tabular}

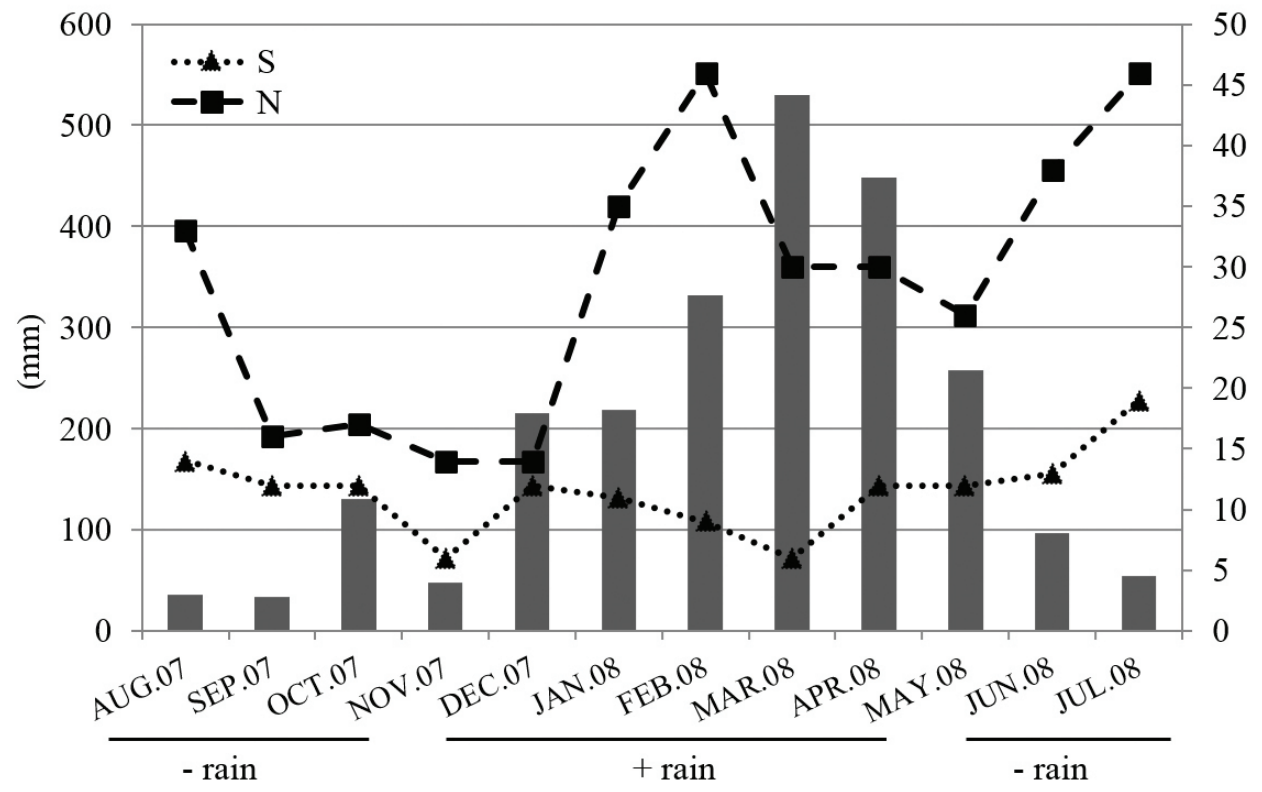

Figure 1. Richness $(\mathrm{S})$ and abundance $(\mathrm{N})$ of species and monthly pluviometric precipitation (bar) in mm for Noctuidae (Lepidoptera, Noctuoidea) collected using light trap in a pasture in Altamira, eastern Amazon, state of Pará, Brazil, from August/2007 to July/2008. 
Table 2. Values of richness (S) and abundance $(\mathrm{N})$ of species, Shannon diversity index (H') * and Brillouin $(\mathrm{H})$ *, Shannon uniformity indexes (E') and Brillouin (E) and dominance of Berger-Parker (BP) for Noctuidae (Lepidoptera, Noctuoidea) caught by a light trap in a pasture in Altamira, eastern Amazon, state of Pará, Brazil, from August/2007 to July/2008 .

\begin{tabular}{|c|c|c|c|c|c|c|c|}
\hline \multirow{2}{*}{ Month/Period } & \multicolumn{7}{|c|}{ Parameters } \\
\hline & $\mathbf{S}$ & $\mathbf{N}$ & $\mathbf{H}^{\prime}$ & $\mathbf{H}$ & $\mathbf{E}^{\prime}$ & $\mathbf{E}$ & BP \\
\hline August & 14 & 33 & 2.35 & 1.90 & 0.89 & 0.90 & 0.242 \\
\hline September & 12 & 16 & 2.43 & 1.74 & 0.98 & 1.00 & 0.125 \\
\hline October & 12 & 17 & 2.36 & 1.72 & 0.95 & 0.97 & 0.176 \\
\hline November & 6 & 14 & 1.67 & 1.26 & 0.93 & 0.94 & 0.385 \\
\hline December & 12 & 14 & 2.44 & 1.70 & 0.98 & 1.00 & 0.143 \\
\hline January & 11 & 35 & 1.98 & 1.63 & 0.82 & 0.82 & 0.371 \\
\hline February & 9 & 46 & 1.40 & 1.19 & 0.64 & 0.62 & 0.609 \\
\hline March & 6 & 30 & 1.40 & 1.18 & 0.78 & 0.77 & 0.400 \\
\hline April & 12 & 30 & 2.00 & 1.59 & 0.81 & 0.80 & 0.400 \\
\hline May & 12 & 26 & 2.36 & 1.86 & 0.95 & 0.95 & 0.115 \\
\hline June & 13 & 38 & 2.05 & 1.68 & 0.80 & 0.79 & 0.342 \\
\hline July & 19 & 46 & 2.69 & 2.22 & 0.91 & 0.92 & 0.196 \\
\hline + Rain & 39 & 181 & $2.61^{\mathrm{t}}$ & 2.34 & 0.71 & 0.71 & 0.381 \\
\hline - Rain & 49 & 164 & $3.33^{t}$ & 2.95 & 0.85 & 0.86 & 0.140 \\
\hline Total & 66 & 345 & 3.20 & 2.94 & 0.76 & 0.76 & 0.252 \\
\hline
\end{tabular}

* (Natural Logarithm); $\mathrm{t}$ = significantly different at $5 \%$ by the " $\mathrm{t}$ "test

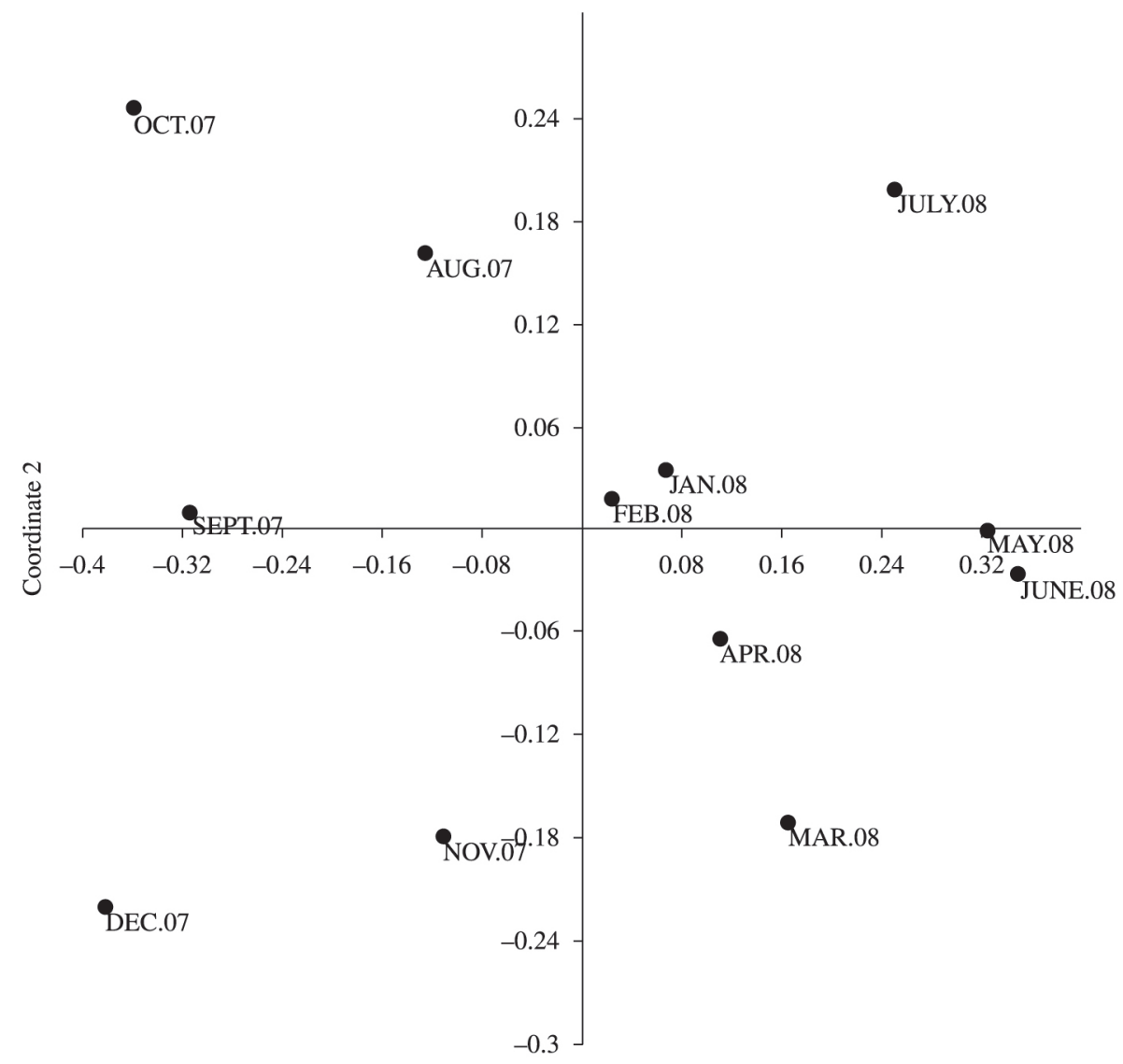

Coordinate 1

Figure 2. NMDS (Bray-Curtis similarity, stress 0.213) for each month based on data of species abundance for Noctuidae (Lepidoptera, Noctuoidea) collected using light trap in a pasture in Altamira, eastern Amazon, state of Pará, Brazil, from August/2007 to July/2008. 
of subfamilies represented in our samples was less to that found in "Campos Sulinos".

The most abundant subfamilies in our present data differ from those found to be abundant in other regions, especially in areas with agricultural occupation, where generally the most representative subfamilies in terms of abundance are the Amphipyrinae and Hadeninae (Tarragó et al., 1975; Specht and Corseuil, 2002; Specht et al., 2005).

Table 3. Estimates of Noctuidae (Lepidoptera, Noctuoidea) caught by a light trap in a pasture in Altamira, eastern Amazon, state of Pará, Brazil, from August/2007 to July/2008. Number of samples, species, number of species represented by only one ("Singletons"), and two exemplars ("doubletons") and species richness, according to several estimators.

\begin{tabular}{lccc}
\hline & \multicolumn{3}{c}{ Period } \\
\cline { 2 - 4 } & +Rain & - Rain & Total \\
\hline Samples & 12 & 12 & 24 \\
Species & 39 & 49 & 66 \\
Unique & 17 & 27 & - \\
"Singletons" & 21 & 23 & 30 \\
"Doubletons" & 5 & 13 & 14 \\
Unicates & 25 & 33 & 36 \\
Duplicates & 6 & 7 & 14 \\
"Bootstrap" & 49 & 62 & 81 \\
"Chao1" & 74 & 64 & 95 \\
"Chao2" & 78 & 110 & 106 \\
"Jackknife1" & 62 & 79 & 100 \\
"Jackknife2" & 78 & 101 & 121 \\
"Michaelis-Mentem" & 178 & 225 & 170 \\
\hline
\end{tabular}

The richness of subfamilies indicates the influence of forests, since Ophiderinae is more diverse in forest environments (Scoble, 1992). Regarding Amphipyrinae and Catocalinae, most species collected in this study (which belong to Condica, Elaphria, Hampsonodes, Spodoptera, Mocis, Perasia and Ptichodes) are often collected in anthropogenic environments associated with cultivated crops, or weeds (Carvalho et al., 1971; Tarragó et al., 1975; Specht and Corseuil, 2002; Specht et al., 2005).

Of the species caught, $59(89.4 \%)$ were represented by less than 10 specimens. Of these, 31 are "singletons" and 13 "doubletons" (Tables 1 and 3). Among the most abundant, $P$. basilans is known to use representatives of Smilacaceae as hosts (Specht et al., 2004). Ptichodes immunis (Guenée, 1852 ) is associated with Fabaceae crops and pastures (Desmodium and Waltheria) (Janzen and Hallwachs, 2009). P. basilans has been mentioned in virtually every Noctuidae inventory; however, never before as the most abundant species (Carvalho et al., 1971; Tarragó et al., 1975; Specht and Corseuil, 2002; Specht et al., 2005). Both L. jaliscana and S. frugiperda are associated with cultivated crops, especially grass (Specht et al., 2004). It is noteworthy that L. jaliscana was the most abundant noctuid in areas with irrigated rice in Rio Grande do Sul (Carvalho et al., 1971). With respect to the representatives of Argidia, the only available information indicates that they are associated with woody plants in Annonaceae, Dichapetalaceae and especially Fabaceae (Janzen and Hallwachs, 2009).

Our results indicate that most of the species collected relate to the introduced pastures, because the owlet moth community sampled in this study did not included the

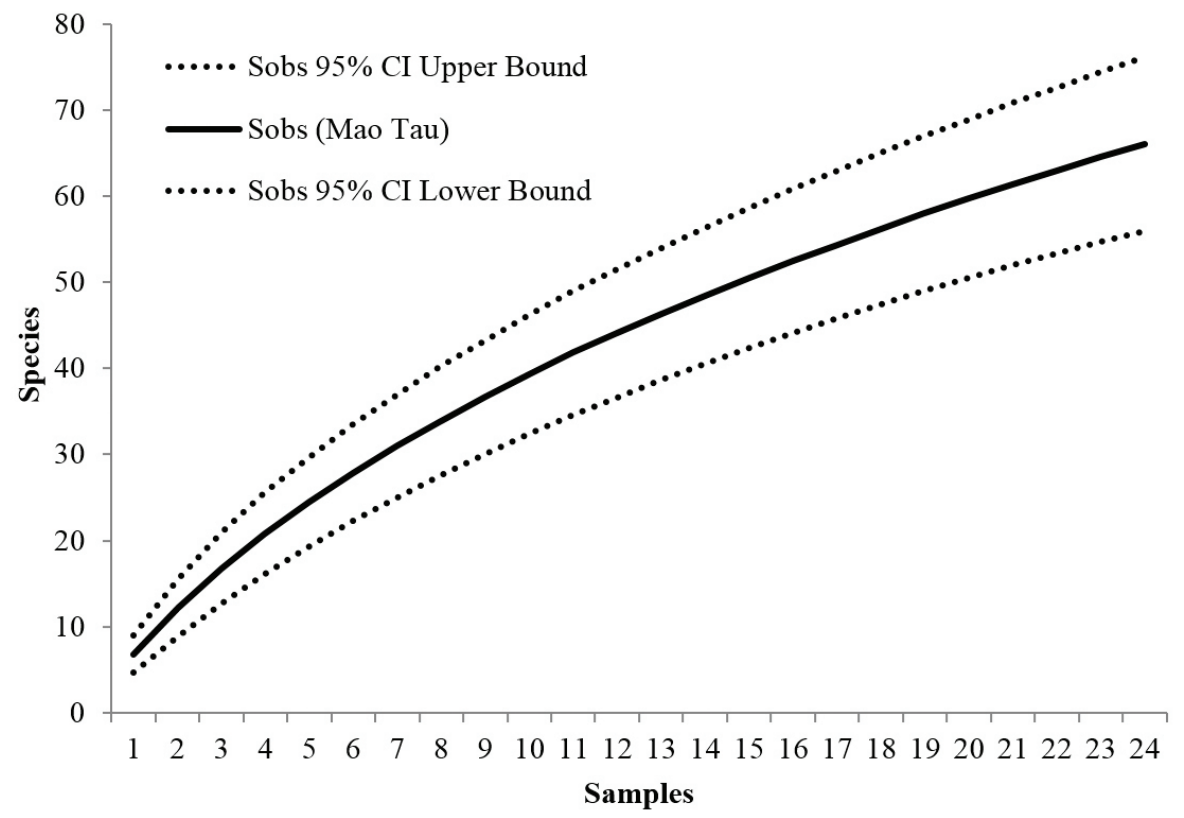

Figure 3. Species rarefaction curve for Noctuidae (Lepidoptera, Noctuoidea) collected using light trap in a pasture in Altamira, eastern Amazon, state of Pará, Brazil, from August/2007 to July/2008. 
predominance of species related with native vegetation, especially grasses, belonging to Amphipyrinae, Hadeninae and Noctuinae (Specht et al., 2004; Specht et al., 2005). Furthermore, of the most abundant species (Table 1) only P. basilans $(\mathrm{n}=3)$ and $S$. frugiperda $(\mathrm{n}=4)$ were represented by few specimens in the "Reserva Biológica do Ibirapuitã", representative of Biome "Campos Sulinos" (Specht et al., 2005).

The constancy data differ greatly from those reported in a study in Rio Grande do Sul conducted in an area belonging to the physiographic area of the "Encosta Superior do Nordeste", where the soil is of basaltic formation and the climate is transitional between tropical and temperate, with rainfall fairly regular throughout the year (Specht and Corseuil, 2002). In that area, $25.9 \%$ of the species were listed as constant, $21.3 \%$ as accessory and $52.8 \%$ as accidental. Interestingly L. jaliscana and $P$. basilans also appear as constant species in the referred study. The accessory species of this study were mostly members of the Ophiderinae, whereas in Rio Grande do Sul they were distributed among all subfamilies. In the dominant categories, with the exception of $A$. palmipes, the species are associated with plants that are prevalent in areas under human influence (Specht et al., 2004). Future studies should evaluate the relationship of $P$. basilans with their host plants.

Considering the entire study period, the values of diversity and evenness were lower and hence the dominance higher than those found for Arctiinae in the same area (Teston and Delfina, 2010).

The NMDS analysis (Figure 2) revealed no clear division between the months with more and less rain, but points to a division between the years, most likely due to low rainfall in August-December 2007.

Between the seasonal periods (Table 3), that with less rain had the highest estimates of richness. Only the "Chao 1" showed a greater value for the period of more rain. The estimate values, coupled with the large number of "singletons" 30 (45.5\%) and "doubletons" 14 (21.2\%) for the total period, point to the need to continued sampling in order better characterize the richness of species in this area, this was also evidenced by the species rarefaction curve (Figure 3).

Our results do not indicate a clear effect of the seasonality on species of this family, except in that less rainfall was associated with greater diversity. In order to draw further conclusions on this matter, it is necessary to continue studies to better characterize the noctuid fauna in the area.

\section{Acknowledgements}

We thank Mr. José Delfino Neto and the biologist Márcia Cristina Delfina, for allowing us to conduct this study in the area, and for help with collecting. We also thank the Altamira meteorology station employees $\left(2^{\circ}\right.$ DISME INMET), for the information provided.

\section{References}

ALVES, DS., 2001. O Processo de desmatamento na Amazônia. Parceiras Estratégicas, vol. 12, p. 259-275.

CARVALHO, S., TARRAGÓ, MFS. and LINK, D., 1971. Captura de noctuídeos através de armadilha luminosa. I-Resultados preliminares. Revista Centro de Ciências Rurais, vol. 1, p. 15-22.

CHEY, VK., HOLLOWAY, JD. and SPEIGHT, MR., 1997. Diversity of moths in forest plantations and natural forests in Sabah. Bulletin of Entomological Research, vol. 87, no. 04, p. 371-385. http://dx.doi.org/10.1017/S000748530003738X.

COLWELL, RK. and CODDINGTON, JA., 1994. Estimating terrestrial biodiversity through extrapolation. Philosophical Transaction of the Royal Society of London. Series B, vol. 345, no. 1311, p. 101-118. http://dx.doi.org/10.1098/rstb.1994.0091. PMid:7972351

COLWELL, RK., 2009. EstimateS: Statistical estimation of species richness and shared species from samples. Version 8.2.0. User's Guide and application. Available from: <http://viceroy. eeb.uconn.edu/EstimateS> Acess in: 14 dec. 2010.

FEARNSIDE, PM., 2005. Desmatamento na Amazônia brasileira: história, índices e consequências. Megadiversidade, vol. 1, p. 113-123.

GASTON, KJ., 1988. Patterns in the local and regional dynamics of moths populations. Oikos, vol. 53, no. 1, p. 49-57. http://dx.doi. org/10.2307/3565662.

HAMMER, Ø., HARPER, DAT. and RYAN, PD., 2001. PAST: Paleontological Statistics software package for education and data analysis. Palaeontologia Electronica, vol. 4, p. 1-9.

HUTCHESON, K., 1970. A test for comparing diversities based on the Shannon formula. Journal of Theoretical Biology, vol. 29, no. 1, p. 151-154. http://dx.doi.org/10.1016/0022-5193(70)901244. PMid:5493290

JANZEN, D. and HALLWACHS, W., 2009. Dynamic database for an inventory of the macrocaterpillar fauna, and its food plants and parasitoids, of Area de Conservación Guanacaste (ACG), Costa Rica. Available from: $<$ http://janzen.sas.upenn.edu $>$ Acess in: 04 jan. 2012.

MAGURRAN, AE., 2004. Measuring Biological Diversity. Oxford: Blackwell Publishing. 260 p.

MORAES, BC., COSTA, JMN., COSTA, ACL. and COSTA, MH., 2005. Variação espacial e temporal da precipitação no estado do Pará. Acta Amazonica, vol. 35, p. 207-214.

OTT, AP. and CARVALHO, GS., 2001. Comunidade de cigarrinhas (Hemiptera: Auchenorrhyncha) de uma área de campo do município de Viamão, Rio Grande do Sul, Brasil. Neotropical Entomology, vol. 30, no. 2, p. 233-243. http://dx.doi.org/10.1590/ S1519-566X2001000200005.

POOLE, RW., 1989. Noctuidae. In HEPPNER, JB. Lepidopterorum catalogus. New York: E.J. Brill. 1314 p.

SALOMÃO, RP., VIEIRA, ICG., SUEMITSU, C., ROSA, NA., AMARAL, DD. and MENEZES, MPM., 2007. As florestas de Belo Monte na grande curva do rio Xingu, Amazônia Oriental. Boletim Museu Paraense Emílio Goeldi. Ciências Naturais, vol. 2, p. 57-153. 
SILVEIRA NETO, S., NAKANO, O., BARDIN, D. and VILLA NOVA, NA., 1976. Manual de ecologia dos insetos. Piracicaba: Agronômica Ceres. 419 p.

SCOBLE, MJ.,1992. The Lepidoptera: Form, Function and Diversity. Oxford: Oxford University Press. 404 p.

SPECHT, A. and CORSEUIL, E., 2002. Diversidade dos noctuídeos (Lepidoptera, Noctuidae) em Salvador do Sul, Rio Grande do Sul, Brasil. Revista Brasileira de Zoologia, vol. 19, p. 281-298. http:// dx.doi.org/10.1590/S0101-81752002000500022.

SPECHT, A., SILVA, EJE. and LINK, D., 2004. Noctuídeos (Lepidoptera, Noctuidae) do Museu Entomológico Ceslau Biezanko, Departamento de Fitossanidade, Faculdade de Agronomia "Eliseu Maciel”, Universidade Federal de Pelotas, RS. Revista Brasileira Agrociência, vol. 10, p. 389-409.

SPECHT, A., TESTON, JA., DI-MARE, RA. and CORSEUIL, E., 2005. Noctuídeos (Lepidoptera, Noctuidae) coletados em quatro
Áreas Estaduais de Conservação do Rio Grande do Sul, Brasil. Revista Brasileira de Entomologia, vol. 49, no. 1, p. 130-140. http://dx.doi.org/10.1590/S0085-56262005000100015.

TARRAGÓ, MFS., CARVALHO, S. and LINK, D., 1975. Levantamento da família Noctuidae, através de armadilhas luminosas, em Santa Maria, RS. Revista Centro de Ciências Rurais, vol. 5, p. 125-130.

TESTON, JA. and DELFINA, MC., 2010. Diversidade de Arctiinae (Lepidoptera, Arctiidae) em área alterada em Altamira, Amazônia Oriental, Pará, Brasil. Acta Amazonica, vol. 40, no. 2, p. 387-396. http://dx.doi.org/10.1590/S0044-59672010000200017.

TESTON, JA., NOVAES, JB. and ALMEIDA JÚNIOR, JOB., 2012. Abundância, Composição e Diversidade de Arctiinae (Lepidoptera, Arctiidae) em um fragmento de floresta na Amazônia Oriental em Altamira, PA, Brasil. Acta Amazonica, vol. 42, no. 1, p. 19-28. http://dx.doi.org/10.1590/S0044-59672012000100013. 